Edukids volume 17 (1) tahun 2020

EDUKIDS: Jurnal Pertumbuhan, Perkembangan, dan Pendidikan Anak Usia Dini

Jln. Dr. Setiabudhi No. 229 Kota Bandung 40154. e-mail: edukid@ upi.edu website: http://ejournal.upi.edu/index.php/edukid

\title{
PENGARUH PEMBELAJARAN SAINS BERBASIS EKSPERIMEN TERHADAP KETERAMPILAN PROSES SAINS PADA ANAK USIA DINI
}

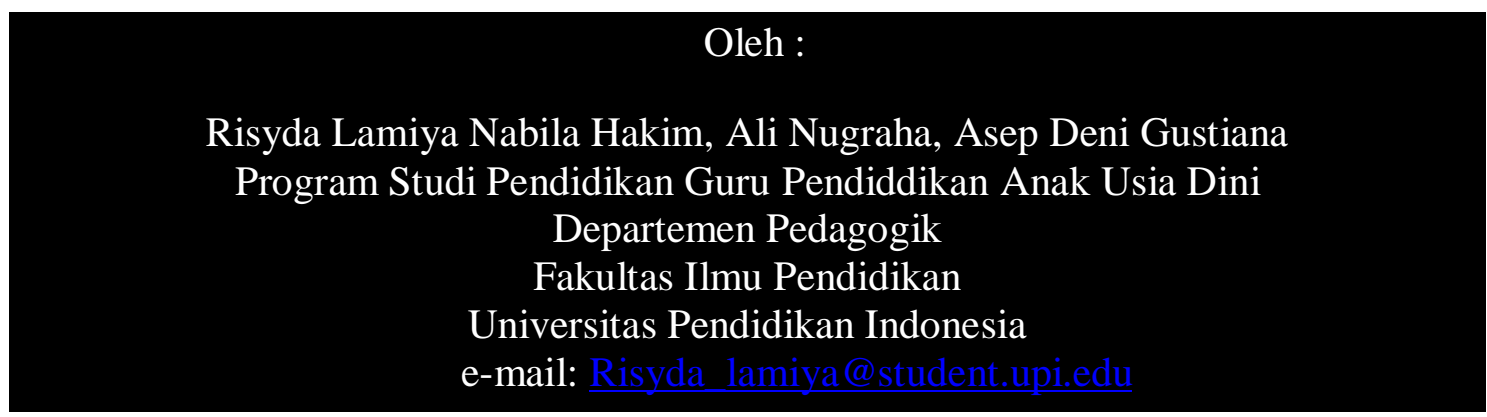

\begin{abstract}
Abstrak: Penelitian ini dilatar belakangi rendahnya pengetahuan anak dalam konsep pembelajaran sains di TK LAB UPI Bandung. Adapun solusi dalam mengatasi permasalahan tersebut yaitu dengan menggunakan pembelajaran sains berbasis eksperimen. Sampel penelitian ini menggunakan subjek penelitian sebanyak 18 anak yang terdiri dari 5 anak perempuan dan 12 anak laki-laki. Metode penelitian yang digunakan peneliti yaitu kuasi eksperimen dengan desain non-equivalent control grup design dengan instrumen penelitian berupa daftar ceklis mengenai keterampilan proses sains anak usia dini. Hasil penelitian menunjukkan bahwa pembelajaran sains berbasis eksperimen memberikan pengaruh terhadap keterampilan proses sains pada anak usia dini. maka dari itu, dapat dijadikan sebuah rekomendasi bagi peneliti selanjutnya untuk menerapkan pembelajaran sains berbasis eksperimen dengan memperbanyak kegiatan eksperimen dalam meningkatkan keterampilan proses sains pada anak usia dini.
\end{abstract}

\section{Kata kunci: keterampilan proses sains, pembelajaran sains, metode eksperimen}

\begin{abstract}
This research motivated by the low level of children's knowledge in the concept of science learning at the LAB UPI Kindergarten in Bandung. The solution to overcome these problems is by using experimental science-based on learning. The sample of this study used 18 research subjects consisting of 5 girls and 12 boys. The research method used by the researcher was quasi-experimental with a non-equivalent control group design with a research instrument in the form of a checklist regarding early childhood science process skills. The results showed that experimental science-based learning had an influence on science process skills in early childhood. therefore, it can be used as a recommendation for future researchers to apply experimental-based science learning by increasing experimental activities in improving science process skills in early childhood.
\end{abstract}

\section{Keywords: science process skills, science learning, experimental methods}

\section{PENDAHULUAN}

Anak Usia Dini menurut National Association for the Education of Young
Children (NAEYC) yaitu asosiasi para pendidik anak yang berpusat di Amerika, membagi anak usia dini menjadi $0-3$ 
tahun, 3-5 tahun, dan 6-8 tahun. Berdasarkan definisi tersebut anak usia dini merupakan kelompok manusia yang berada pada proses pertumbuhan dan perkembangan yang memiliki pola pertumbuhan dan perkembangan fisik, kognitif, sosio-emosional, kreativitas, bahasa dan komunikasi yang khusus sesuai dengan tahapan yang sedang dilalui oleh anak tersebut.

Menurut pasal 28 Undang-undang Sistem Pendidikan Nasional Nomor 20 tahun 2003 ayat 1, disebutkan bahwa anak yang termasuk anak usia dini adalah anak yang masuk dalam rentang usia 0-6 tahun. Usia dini merupakan masa keemasan (golden age), di mana usia tersebut sangat menentukan dalam pembentukan karakter dan kepribadian seorang anak. Beberapa orang menyebutkan masa golden ages sangat menentukan akan seperti apa mereka ketika tumbuh dewasa, baik dari segi fisik, mental maupun kecerdasan.

Berdasarkan beberapa definisi megenai anak usia dini dapat disimpulkan bahwa anak usia dini adalah sosok individu yang berada pada rentang usia 06 tahun yang sedang menjalani suatu proses perkembangan dengan pesat yang sangat menentukan seperti apa kelak ketika mereka dewasa.

Hariwijaya (2007, hlm.10) mengemukakan bahwa PAUD dapat diartikan sebagai salah satu bentuk jalur pendidikan dari usia 0-6 tahun, yang diselenggarakan secara terpadu dalam satu program pembelajaran agar anak dapat mengembangkan semua potensi dan kreatifitas sesuai dengan karakteristik perkembangannya. Pentingnya pengembangan pembelajaran sains pada anak usia dini sudah disadari oleh semua pihak karena pada usia dinilah otak individu berkembang sangat pesat. Proses pertumbuhan otak berjalan sesuai dengan pertumbuhan badan. Ketika seorang anak berusia 5 tahun, pertumbuhan otaknya sudah $80 \%$ sempurna. Implikasinya pada bidang pendidikan usia dini adalah diperlukan langkah yang tepat (signifikan dan strategis) untuk membekali anak sejak usia tersebut.

Abruscato (dalam Aisyah, dkk, 2007, hlm.12) menilai bahwa kegiatan sekolah yang pada umumnya digunakan untuk mengasah daya pikir dan menyerap pengetahuan merupakan hal yang keliru. Sehubung dengan teori perkembangan kognitif, hal terpenting adalah bagaimana anak dapat mengingat dan menerapkan yang diperolehnya, serta bagaimana ia dapat menggunakan konsep dan prinsip yang dipelajarinya. Jadi nilai sesungguhnya dari sifat pengembangan kognitif harus mengarah pada isi dan proses. Dalam mengarahkan anak untuk menguasai isi pengetahuan, dilakukan melalui proses atau aktivitas yang bermakna dengan memfasilitasi yang mencakup dimensi isi maupun proses tersebut, missal, melalui observasi, membaca, diskusi, eksperimen, atau media yang relevan. Selain itu, ketepatan guru dalam melaksanakan pembelajaran akan berdampak positif pada anak dalam jangka pendek maupun jangka panjang bagi kehidupan anak. Berdasarkan pengalaman pada masa kecil yang merupakan bagian kehidupan seseorang di masa depannya, kegiatan-kegiatan masa kecil seseorang, merupakan simulasi bagi kehidupan dewasanya.

Sedangkan menurut (Poedjiadi, 2010, hlm.77) mengemukakan bahwa perkembangan sains terjadi karena adanya keingintahuan seseorang tentang suatu peristiwa yang terjadi dalam alam, langkah tersebut dilakukan untuk mengembangkan suatu ilmu. Pengembangan pembelajaran sains pada anak, termasuk bidang pengembangan lainnya yang memiliki peranan sangat penting dalam membantu perkembangan kognitif pada anak usia dini (Roza, 2012, hlm.12). Kesadaran pentingnya pembekalan sains pada anak akan semakin tinggi apabila menyadari bahwa 
kita hidup pada dunia yang dinamis, berkembang dan berubah secara terus menerus menuju masa dewasa, semakin kompleks ruang lingkupnya, dan tentunya akan semakin memerlukan sains. Conant dalam (Nugraha, 2008, hlm.3) mendefenisikan sains sebagai suatu deretan konsep serta skema konseptual yang berhubungan satu sama lain, yang tumbuh sebagai hasil serangkaian percobaan dan pengamatan serta dapat diamati dan di uji coba lebih lanjut yang berhubungan erat dengan kegiatan penelusuran gejala dan fakta alam yang ada di sekitar anak.

Arsyad (dalam Aisyah, dkk, 2007, hlm.23) mengatakan bahwa keterampilan proses sains merupakan kemampuan pada anak untuk mengelola (memperoleh) yang didapat dalam kegiatan belajar mengajar (KBM) anak dapat mengembangkan fungsi kognitif dasar sedangkan menurut Vygotsky (dalam Moeslichatoen, 2004, hlm.17) kognitif adalah kemampuan memperhatikan, mengamati, dan mengingat saat proses KBM yang sesuai dengan keterampilan proses sains yang dikembangkan.

Salah satu upaya untuk mengembangkan aspek perkembangan pada anak usia dini adalah dengan cara mengenalkan sains, yaitu kemampuan berpikir konseptual dan mengembangkan logika anak sedini mungkin. Upaya melihat pencapaian tingkat perkembangan keterampilan proses sains pada anak dimulai dengan mengikutsertakan anak dalam kegiatan percobaan sederhana secara langsung. Selain itu, Piaget (dalam Barbara, 1993, hlm.71) menyatakan bahwa pembelajaran berdasarkan pengalaman pada anak memudahkan anak untuk mendapatkan ilmu pengetahuan yang nyata dan baru. Oleh karena itu, menggunakan pembelajaran sains berbasis eksperimen dengan melakukan kegiatan yang kongkrit, serta memberikan pengalaman nyata kepada anak dengan pembelajaran yang dikemas menyenangkan akan menarik minat anak dan pengetahuan barunya akan sangat mempengaruhi perkembangan sel otak anak.

Montolalu (dalam Setyowati, 2014, hlm.17) mengajarkan sains sedini mungkin agar anak-anak ikut berpartisipasi dalam proses ilmiah karena keterampilan yang mereka dapatkan bisa dibawa sebagai keterampilan yang bermanfaat selama hidupnya. Keterampilan proses telah lama dilaksanakan di negara Inggris dan disebut Science A Process Approach (SAPA) yang bertujuan agar anak sejak dini dibiasakan untuk mencari masalah kemudian melakukan langkah-langkah seperti yang ilmuan lakukan dalam menemukan fakta atau teori baru (Poedjiadi, 2010, hlm.78). Oleh karena itu, Nugraha (2008, hlm.152-154) menyatakan tentang keterampilan proses sains anak meliputi, keterampilan mengamati, mengelompokkan, mengomunikasikan, menggunakan angka dan hitungan, menyimpulkan (inferensi) dan keterampilan memprediksi (memperkirakan). Melalui sains, anak dapat melakukan percobaan sederhana yang berguna untuk melatih anak dalam menghubungkan sebab dan akibat dari suatu perlakuan, sehingga melatih anak untuk berpikir logis (Suyanto, 2015, hlm.2). Sehubungan dengan hal tersebut Taylor (1993, hlm .5) mengatakan dalam menggunakan pembelajaran sains guru dan murid sama-sama mendapatkan perubahan sikap yang positif. Oleh karena itu, bila anak usia dini diberi kesempatan untuk bereksperimen, mencoba, menguji dengan berbagai sumber belajar mereka akan memperoleh penyempurnaan dalam cara kerja mereka juga dapat mengapresiasi cara kerja anak lain. Adanya kegiatan mengamati, memberikan peluang kepada anak untuk menumbuhkan rasa keingintahuannya yang besar dan menjadi ciri karakteristiknya. Selanjutnya dari 
pengamatan yang dilakukan akan menimbulkan dorongan untuk mencoba atau mengenal lebih lanjut tentang apa yang telah diamatinya. Berdasarkan aktivitas pengamatan dan percobaan, pada akhirnya memberikan kesempatan kepada anak untuk membangun pengetahuan baru sesuai dengan tahap perkembangan kognitifnya, sehingga anak mampu mengelompokkan bendabenda sesuai dengan jenis dan fungsinya, meskipun tidak semuanya benar. Berdasarkan pendapat beberapa ahli mengenai metode eksperimen:

$$
\text { "...The method using }
$$

experimental activities gives the opportunity to develop cognitive skills easily and further it gives a lot of opportunities for the students to work in groups or alone. Further, via this method students are also given opportunity to learn by drill and practice. Experimental activities encourage affect reasoning, critical thinking, the understanding of science and also help students to develop the ways of producing knowledge" (Duru, 2010, hlm.7).

Menurut Dale (dalam Anderson, 2007, hlm.6) model pembelajaran yang menekankan pada pembelajaran berbasis proses, dengan memperoleh informasi berdasarkan pengalaman. Penelitian Dale mengatakan bahwa model pembelajaran secara langsung atau yang biasa disebut dengan pembelajaran eksperimen akan lebih banyak informasi yang didapat menggunakan pembelajaran berbasis proses dibandingkan mengenai apa yang mereka "lakukan" apa yang mereka "dengar", "membaca" atau "observasi" sekalipun. Oleh karena itu, anak perlu dimotivasi untuk mengungkapkan apa yang diperoleh dari pembelajaran berdasarkan pengalaman sehingga dapat diketahui benar dan tidaknya pengetahuan pada anak. Berdasarkan fenomena dari pengamatan yang peneliti temukan dilapangan ternyata masih banyak anak usia dini di Taman Kanakkanak yang dikategorikan kurang dalam membangun pengetahuan baru sesuai dengan pengalamannya. Adapun kurangnya pengetahuan anak dalam konsep pembelajaran sains dikarenakan metode pembelajaran sains berbasis eksperime $\neg n$ yang masih langka pelaksanaannya dalam melakukan sebuah percobaan sederhana.

Dalam penelitian yang telah dilakukan oleh (Wijayanti, 2009, hlm.4) pada anak di Taman Kanak-kanak Kartika KPAD Gegerkalong Bandung mengenai pengaruh metode pembelajaran eksperimen terhadap keterampilan proses sains anak. penelitian tersebut mengemukakan bahwa hasil proses pembelajaran keterampilan proses sains anak sebelum perlakuan, menerapkan metode pembelajaran eksperimen terhadap keterampilan proses sains anak. Bentuk perlakuan yang ditemukan yaitu metode eskperimen dengan materi fisika.

Berbeda dengan penelitian sebelumnya, penelitian ini lebih menitik beratkan pada pembelajaran sains berbasis eksperimen yang di dalamnya terdapat berbagai kegiatan percobaan sains sederhana menggunakan metode pembelajaran berbasis eksperimen dengan berbagai muatan materi sains yang telah ditentukan dan disesuaikan dengan kebutuhan anak, khususnya pemahaman tentang keterampilan proses sains yang meliputi aspek pengamatan, percobaan, pengukuran, dan menarik kesimpulan melalui pembelajaran sains berbasis eksperimen dengan memberikan kesempatan kepada anak untuk menemukan dan mengasah keterampilan proses sains.

Fokus masalah pada penelitian ini adalah untuk mengetahui pengaruh pembelajaran sains berbasis eksperimen terhadap keterampilan proses pada anak usia dini agar mereka terlibat dan mengalami secara langsung dalam sebuah percobaan serta membuat anak lebih 
yakin atas hasil yang mereka dapat. Penerapan pembelajaran sains berbasis eksperimen ini anak akan lebih paham dan mengerti akan suatu permasalahan yang mereka hadapi daripada anak yang hanya menerima informasi. Selain itu, diharapkan dapat membantu meningkatkan keterampilan proses sains pada anak. Oleh karena itu, peneliti menggunakan judul Pengaruh Pembelajaran Sains Berbasis Eksperimen Terhadap Keterampilan Proses Sains Pada Anak Usia Dini.

Dari uraian masalah yang telah dijelaskan sebelumnya, penelitian ini mengangkat judul "Pengaruh Pembelajaran Sains Berbasis Eksperimen Terhadap Keterampilan Proses Sains Pada Anak Usia Dini”.

Berdasarkan latar belakang masalah di atas maka terurailah beberapa masalah dalam penelitian, antara lain:

1. Bagaimana keterampilan proses sains anak sebelum menggunakan pembelajaran sains berbasis eksperimen pada anak kelompok B Taman kanak-kanak Lab UPI Bandung?

2. Bagaimana keterampilan proses sains anak sesudah menggunakan pembelajaran sains berbasis eksperimen pada anak kelompok Taman kanak-kanak Lab UPI Bandung?

3. Apakah terdapat pengaruh yang signifikan dari penerapan pembelajaran sains berbasis eksperimen terhadap keterampilan proses sains pada anak kelompok B Taman kanak-kanak Lab UPI Bandung?

Mengacu pada rumusan masalah di atas, maka tujuan penelitian ini adalah sebagai berikut:

1. Untuk mengetahui keterampilan proses sains anak-anak sebelum menggunakan pembelajaran sains berbasis eksperimen pada anak kelompok B Taman kanak-kanak Lab UPI Bandung.

2. Untuk mengetahui keterampilan proses sains anak-anak sesudah menggunakan pembelajaran sains berbasis eksperimen pada anak kelompok B Taman kanak-kanak Lab UPI Bandung.

3. Untuk mengetahui pengaruh pembelajaran sains berbasis eksperimen terhadap keterampilan proses sains pada anak kelompok B Taman kanak-kanak Lab UPI Bandung.

Hipotesis yang akan diuji dalam penelitian ini adalah:

$H_{0}: r_{x y}=0$; Artinya tidak terdapat pengaruh yang signifikan antara keterampilan proses sains (X) dengan pembelajaran sains berbasis eksperimen (Y) pada anak usia dini.

$H a: r_{x y} \neq 0$; Terdapat pengaruh

yang signifikan antara

keterampilan proses sains (X)

dengan pembelajaran sains

berbasis eksperimen (Y) pada anak usia dini.

\section{METODE}

Penelitian ini termasuk pada pendekatan kuantitatif, adalah satu bentuk penelitian ilmiah yang mengkaji satu permasalahan dari suatu fenomena, serta melihat kemungkinan kaitan atau hubungan-hubungannya antarvariabel dalam permasalahan yang ditetapkan (Indrawan \& Yaniawati, 2014, hlm.51). Metode penelitian yang digunakan dalam penelitian ini adalah quasi experimental design (eksperimental-semu) yang bertujuan untuk memperoleh informasi yang merupakan perkiraan bagi informasi yang dapat diperoleh dengan eksperimen yang sebenarnya dalam keadaan yang tidak memungkinkan untuk mengontrol atau memanipulasi variabel yang relevan (Suryabrata, 2011, hlm.92) selain itu diungkapkan oleh Creswell (dalam 
Indrawan \& Yaniawati, 2014, hlm.58) perbedaan pra-eksperimen dengan eksperimental semu bahwa subjek penelitian ini mengikuti pembagian kelas yang sudah ada namun sudah menggunakan kelompok kontrol, di mana salah satu diberi perlakuan sedang yang lain tidak, dan keduanya diberikan dua kali tes, yaitu tes sebelum dan tes sesudah perlakuan. Adapun yang dimaksud keteraampilan proses sains dalam penelitian ini adalah skor penilaian tester terhadap keterampilan proses sains anak yang dilihat dari keterampilan: a). mengamati. b). mengklasfikasi dan d). mengomunikasikan temuan.

Teknik pengambilan data yang digunakan dalam penelitian adalah teknik observasi terstruktur menurut (Sugiyono, 2016, hlm.215) observasi terstuktur adalah observasi yang telah dirancang secara sistematis, tentang apa yang akan diamati, kapan dan dimana tempatnya dan dokumentasi dalam penelitian ini, teknik ini digunakan untuk memperoleh data tentang anak kelas B di TK Lab UPI dan foto selama waktu pembelajaran penelitian.

Lokasi penelitian ini adalah TK Lab UPI yang berada di kota Bandung.

Populasi penelitian adalah populasi dalam penelitian ini adalah siswa kelas B di TK Lab UPI pada semester dua. Jumlah sampel dalam penelitian in adalah sebanyak 18 orang.

Dalam penelitian ini instrumen yang digunakan merupakan daftar ceklis, daftar cek adalah suatu daftar yang memuat item-item pernyataan tentang aspek-aspek yang mungkin muncul terjadi dalam suatu situasi, tingkahlaku, atau kegiatan individu yang diamati. Semua aspek tingkah laku, situasi yang akan diamati telah dinyatakan dalam suatu daftar.

Instrumen ini akan diberikan dan diisi oleh observer secara langsung di lapangan. Observer diminta untuk mengisi seluruh item pernyataan yang terdapat dalam instrumen dengan cara memilih salah satu alternatif jawaban dari tiga altenatif jawaban, yaitu: Baik (B), Cukup (Cukup) dan Kurang (Kurang). Jawaban diberikan dengan cara memberi tanda ceklis $(\sqrt{ })$ pada salah satu kolom jawaban yang disediakan. Instrumen tersebut memiliki nilai tersendiri yang sesuai dengan alternatif pilihan jawaban. Item instrumen yang tidak valid menurut adjudgment ahli sebanyak 1 butir pada peryataan ke-empat. Dan setelah instrumen penelitiannya disesuaikan kembali pada penelitian ini dengan di ujicobakan menggunakan sampel sebanyak 20, dan dengan menggunakan penghitungan software SPSS setelah dilakukan uji Validitas dan Realibiltas, maka didapatkan hasil dari 8 butir pertanyaan masing-masing variabelnya valid.

\section{HASIL DAN PEMBAHASAN}

\section{Keterampilan Proses Sains Sebelum Treatmen (Hasil pre-test)}

Kondisi awal mengenai keterampilan proses sains anak pada kelompok kontrol dan kelompok eksperimen sebelum pembelajaran sains berbasis eksperimen berada dalam kategori K (Kurang). Pada kelompok kontrol terdapat 9 orang anak dengan kategori kurang dengan nilai rata-rata $(55,55 \%)$ untuk keterampilan prosesnya. Sementara itu di kelompok eksperimen sebanyak 8 orang anak berada pada kategori $\mathrm{K}$ (Kurang) dengan rata-rata $(52,91 \%), 1$ orang $(7,93 \%)$ dengan kategori C (cukup) dan belum ada anak di kategori B (Baik). Secara keseluruhan pada kondisi awal baik kelompok kontrol maupun kelompok eksperimen belum ada anak yang mencapai kategori B (Baik). Seperti pada grafik dibawah ini: 


\section{Diagram 4.1 \\ Persentase Keterampilan Proses Sains Sebelum Treatmen (Hasil Pre-Test)}

pre-test kontrol $\square$ pre-test eksperimen

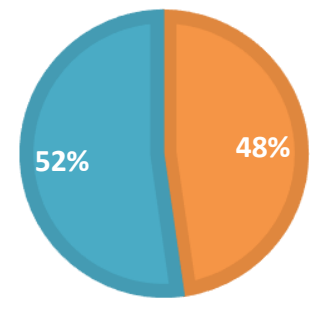

Berdasarkan pengamatan peneliti, sebelum penerapan penerapan pembelajaran konvensional di kelompok kontrol dan pembelajaran sains berbasis eksperimen di kelompok eksperimen kondisi kurangnya keterampillan proses sains anak di sekolah ditunjukkan dengan berbagai sikap. Anak-anak menunjukkan sikap seperti tidak mengamati alat dan bahan dalam percobaan, belum bisa menceritakan kembali tentang percobaan yang telah dilakukan, tidak menyimpulkan hasil eksperimen dan tidak memperkirakan apa yang terjadi terhadap percobaan. Kemudian masih ada anak yang belum mengenal tentang percobaan sederhana atau pembelajaran sains. Selain itu anak belum menunjukkan keterampilan proses terhadap pembelajaran sains menggunakan percobaan sederhana. Hal ini menunjukkan masih kurangnya keterampilan proses sains anak yang menyebabkan anak memiliki keterampilan proses sains seperti mengamati, memprediksi dan menyimpulkan yang rendah.

Dalam hal ini didukung oleh pendapat (Poedjiaji, 2010, hlm.78) bahwa ilmuan dapat mengembangkan imunya melalui suatu proses, yaitu keterampilan proses yang dimilikinya.

Kondisi masih kurangnya keterampilan proses sains pada anak kelompok kontrol dan kelompok eksperimen kemungkinan tidak terlepas dari faktor stimulus (pengetahuan dan pembiasaan) yang anak-anak terima selama ini baik disekolah maupun dirumah dengan orangtua, seperti jarangnya diikut sertakan dalam suatu percobaan, tidak adanya pembelajaran sains atau eksperimen dalam rencana kegiatan harian, kemudian kurangnya pembiasaan untuk meningkatkan keterampilan proses salah satunya seperti keterampilan menyimpulkan oleh sendiri karena terbiasa diberikan kesimpulan oleh guru dan orangtua yang langsung memberikan kesimpulannya tanpa melibatkan anak untuk andil dalam hasil kesimpulan.

Berdasarkan pemaparan diatas, dapat disimpulkan bahwa kurangnya keterampilan proses sains pada anak karena masih kurangnya pemberian stimulus tentang keterampilan proses pada anak baik dilingkungan sekolah bersama guru atau dilingkungan rumah bersama orangtua, Untuk meningkatkan keterampilan proses sains dan bagaimana pentingnya keterampilan proses sains anak untuk kehidupan selanjutnya pihak guru dan orangtua harus menggunakan stimulus yang tepat.

\section{Keterampilan Proses Sesudah Treatmen (Hasil post-test)}

Kondisi akhir keteramilan proses sains anak kelompok kontrol dan kelompok eksperimen di TK Lab UPI Bandung setelah dilakukan pembelajaran sains berbasis eksperimen pada kelompok sebanyak 9 anak berada pada kategori cukup dengan persentase $(71,95 \%)$ dan kemudian 9 orang anak pada kelompok eksperimen berada pada kategori baik dengan persentase $(94,70 \%)$ untuk meningkatkan keterampilan proses sains dilakukan melalui metode eksperimen sebanyak 6 kali pertemuan, dimana setiap anak dilibatkan dalam setiap proses percobaan sederhana.

Peningkatan keterampilan proses sains pada anak dapat terlihat dari anak 
yang mampu mengamati alat dan bahan dalam percobaan, bisa menceritakan kembali tentang percobaan yang telah dilakukan, menyimpulkan hasil eksperimen dan memperkirakan apa yang terjadi terhadap percobaan. Kemudian munculnya sikap ingin tahu pada anak mengenai hasil dari percobaan sains sederhana yang dilakukan. Dapat digambarkan melalui grafik berikut ini:

\section{Diagram 4.2}

Persentase Keterampilan Proses

Sesudah Treatmen (Hasil Post-Test)

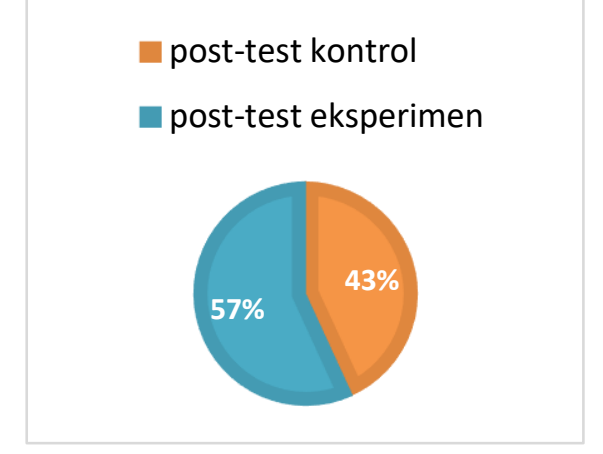

Berdasarkan uraian diatas dapat diketahui bahwa pembelajaran sains berbasis eksperimen dengan metode eksperimen pada kelas eksperimen mengalami peningkatan yang signifikan, dibandingkan dengan kelompok control yang hanya menggunakan pembelajaran konvensional. Dalam pembelajaran sains berbasis eksperimen anak lebih banyak dilibatkan dalam kegiatan percobaan sederhana dan diikut sertakan dalam mengamati alat dan bahan yang digunakan dan ditunjukkan bagaimana menyelesaikan suatu masalah menggunakan keterampilan proses sains.

Secara garis besar keterampilan proses sains pada anak akan meningkat apabila diberikan stimulus berupa pebelajaran sains berbasis eksperimen yang disesuaikan untuk mendukung keterampilan proses sains, seperti pembelajaran sains berbasis eksperimen yang menyediakan pembelajaran nyata bagi anak untuk melakukan suatu percobaan sederhana. Sebaliknya dalam pembelajaran konvensional tidak melibatkan anak dalam suatu percobaan sederhana serta pengalaman nyata (hands on experience) bagi anak. sebagai mana dikemukakan oleh Harlen dan Jelly (dalam Oliver dan Boyd, 1989, hlm.5) Belajar sains merupakan tindakan yang mereka lakukan sendiri dengan membuat kesimpulan dari hasil kegiatan yang telah mereka lakukan melalui pemikiran mereka sendiri.

\section{Pengaruh Pembelajaran Sains Berbasis Eksperimen Terhadap Keterampilan Proses Sains Pada Anak Kelompok B TK Lab UPI Bandung}

Hasil uji stastistik yang telah dilakukan sebelumnya, Pembelajaran sains berbasis eksperimen pada anak dapat memberikan pengaruh terhadap keterampilan proses sains, hal ini terlihat dari uji independent sample $\mathrm{T}$ test data post-test dimana memiliki nilai dengan sig level $=0,000<0,05$. Dengan demikian, maka dapat disimpulkan bahwa uji Independent Sample T Test data post-test kelompok kontrol dan kelompok eksperimen adalah signifikan $(\mathrm{Ho}=$ ditolak dan $\mathrm{Ha}$ diterima $)$, karena nilai $\mathrm{p}$ lebih besar dari 0,05 . Hal ini berarti terdapat perbedaan yang signifikan antara kelompok kontrol dan kelompok eksperimen sesudah dilakukan treatmen, dengan kata lain terdapat pengaruh yang signifikan sesudah pembelajaran dilaksanakan.

Penggunaan Eksperimen di abad ke tujuh belas bertujuan agar suatu percobaan dapat dikembangkan oleh public secara langsung atas pembuktian suatu teori menurut (Weinberg, 2015, hlm.181-190)

Pembelajaran eksperimen merupakan suatu pembelajaran yang didalamnya melibatka kegiatan mengamati. Sehubung dengan itu, 
Harlen dan Jelly (dalam Oliver dan Boyd, 1989, hlm.6) mengemukakan bahwa anak-anak akan sibuk dengan kegiatan yang memiliki tujuan dalam pembelajaran sains melalui proses mengamati. Selain itu, Menurut Wellington (dalam, White, 1991, hlm.5) Dalam dunia sains, keterampilan proses merupakan hal yang sangat penting. Keterampilan proses sains memiliki tiga konsep sains yaitu sains konsep, keterampilan proses sains, dan sikap sains. Dan yang termasuk keterampilan proses sains yaitu keterampilan mengamati, hipotesa, prediksi, investigasi, berkomunikasi serta merancang dan membuat menurut Harlen dan Jelly (dalam Oliver dan Boyd, 1989, hlm.7-38).

Pada tahap pertama atau tahap persiapan yang terdiri dari enam kali kali pertemuan, dengan rencana kegiatan harian (RKH) yang mencakup kegiatan pembukaan, inti dan penutup. Dengan berbagai materi meliputi, materi pencapuran warna dan kapilaritas, materi massa jenis, materi perbedaan zat cair, materi polimer, perbedaan zat (lemak) dan medan magnet. Dimana pada tahap persiapan anak-anak diajak untuk melihat beberapa alat dan bahan yang akan digunakan dalam percobaan sederhana, anak mengamati langsung alat dan bahan yang telah disediakan. Peneliti menyediakan alat dan bahan untuk percobaan seperti air, pewarna makanan, gelas pelastik, tissue kering, kertas, penggaris, pensil, klip besi, klip kayu dan magnet untuk diamati oleh anak. setiap oertemuan anak diajak mendiskusikan hasil temuan tentang percobaan sederhana yang telah dilakukan.

Tahap selanjutnya adalah tahap persiapan percobaan. Alat dan bahan yang digunakan seperti gelas pelastik, air, tissue kering dan pewarna makanan. Dimana anak diarahkan untuk melakukan percobaan dengan dicontohkan oleh guru terlebih dahulu untuk kelas eksperimen dan untuk kelas kontrol anak diperlihatkan alat dan bahan yang akan digunakan. Tahap selanjutnya peneliti mengajak anak untuk duduk didepan alat dan bahan yang telah disediakan diatas meja untuk melakukan percobaan, pada tahap melakukan percobaan yang dilaksanakan dengan 6 pertemuan dengan materi yang berbeda.

Pada pertemuan pertama peneliti membawa alat dan bahan percobaan mengenai warna dan kapilaritas. Dimana anak diajak untuk melakukan percobaan sesuai tahapan yang telah dijelaskan sebelumnya oleh guru pada anak kelompok eksperimen, sedangkan pada anak kelompok kontrol anak diajak untuk melihat proses penyerapan yang terjadi pada percobaan sederhana yang dilakukan oleh guru. Pada tahap ini anak diajak untuk memperkirakan warna yang dihasilkan dari campuran kedua warna pada gelas pelastik setelah itu, anak diajak untuk menyimpulkan hasil pada percobaan mengenai warna dan kapilaritas. Selain itu (Campfireak, 2012, hlm.2) menyatakan bahwa "Walking Water Learn the science about capillaries and mixing colors. We will learn about how water can move UP through roots and we will also learn about how colors mix". Dengan demikian belajar sains tentang kapilaritas dan pencampuran warna. kita akan mempelajari bagaimana pergerakan naiknya air pada akar dan kita juga akan belajar tentang cara menghasilkan warna dengan mencampurkannya.

Pada pertemuan kedua, peneliti mengajak anak untuk melakukan percobaan perbedaan massa jenis benda dengan materi benda tenggelam dan terapung. Peneliti memperlihatkan alat dan bahan yang akan mereka dapatkan saat melakukan percobaan, seperti air, gabus, busa ati, manik-manik, kelereng dan uang koin. Pada kelompok 
eksperimen anak-anak dipersilahkan untuk melakukan tahapan percobaan sedangkan dikelas kontrol anak dipersilahkan untuk melihat percobaan yang dilakukan oleh guru. Pada percobaan ini anak diajak untuk membedakan dan menyebutkan benda yang termasuk benda tenggelam dan benda yang termasuk benda terapung diatas air. Selain itu, menurut (Kong, dkk, 2004, hlm.64) gerakan daya apung tidak hanya bergantung pada berat tetapi juga volume.

Pada pertemuan ketiga, peneliti mengajak anak untuk melakukan percobaan perbedaan zat dengan materi polimer. Peneliti memperlihatkan alat dan bahan yang akan mereka dapatkan saat melakukan percobaan, seperti tusuk sate, air dan pelastik. Selain itu, kantong pelastik terbuat dari polimer yang mempunyai rantai kimia yang panjang. Karena rantai kimia yang panjang itulah maka pelastik mempunyai sifat lebih fleksibel. Ketika ujung tusuk sate yang runcing ditusukkan pada kantong plastik, maka rantai kimia yang panjang itu menutup rapat-rapat sekitar (permukaan) pensil sehingga air tidak mau keluar dari kantung pelastik.

Pada pertemuan keempat, peneliti mengajak anak untuk melakukan percobaan perbedaan zat cair dengan materi lava warna. Peneliti memperlihatkan alat dan bahan yang akan mereka dapatkan saat melakukan percobaan, seperti gelas pelastik, air berwarna, minyak dan tablet effervescent. Selain itu, lava warna yang merupakan pencampuran air, minyak, pewarna, dan tablet effervescent yang digabung masing-masing secara terpisah akan memperlihatkan perbedaan zat cair ketika digabungkan dalam suatu wadah.

Pada pertemuan kelima, peneliti mengajak anak untuk melakukan percobaan perbedaan zat cair (lemak) dengan materi susu pelangi. Peneliti memperlihatkan alat dan bahan yang akan mereka dapatkan saat melakukan percobaan, seperti piring kertas, susu sapi cair putih, cotton bud, sabun cuci piring dan pewarna makanan. Selain itu, Susu memiliki kandungan protein dan lemak. Kemudian protein dan lemak itu bersifat sensitive terhadap lingkungan di sekitarnya, sehingga ketika diberikan sabun, terlihat setetes warna di susu itu menjauh dari sabun, melebar, dan berpendar keluar dan berputar. Hasil reaksinya warna pelangi yang bagus. Sehingga menjadi susu pelangi.

Pada pertemuan keenam, peneliti mengajak anak untuk melakukan percobaan perbedaan medan magnet dengan materi magnet. Peneliti memperlihatkan alat dan bahan yang akan mereka dapatkan saat melakukan percobaan, seperti kertas, penggaris besi, penggaris pelastik, klip kayu, klip besi, uang koin, pensil, gunting pelastik dan gunting besi. Selain itu, kegiatan bermain magnet merupakan salah satu kegiatan populer untuk anak-anak dan guru, dengan bermain percobaan magnet yang dapat dilakukan adalah membedakan bentuknya, mencoba menarik benda berbahan besi dan mencobanya menempelkan dengan bermacam-macam bahan pada magnet (Raper dan Stringer, 1987, hlm.103).

Keterampilan proses sains pada anak usia dini dapat meningkat disebabkan anak diajak untuk mengamati alat dan bahan saat percobaan berlangsung kemudian anak diajak untuk mengelompokkan beberapa alat dan bahan yang sudah digunakan dan juga anak diajak untuk menyimpulkan mengenai hasil percobaan yang telah dilakukan dan juga dengan adanya stimulus yang tepat berupa pembelajaran sains berbasis eksperimen dengan melibatkan anak secara langsung kedalam proses pembelajaran. Sehubung dengan yang dikemukakan oleh Druxes (dalam Fitri, 2013, hlm.17) pelaksanaan pembelajaran eksperimen sebagai 
berikut: (1) Sebagai usaha perkenalan. Anak diajak untuk berkenalan dengan alat, bahan serta cara kerja alat tersebut. Disamping itu anak diajak untuk mengenal suatu konsep dengan berdasarkan alat kerja tersebut, (2) Eksperimen sebagi usaha kejutan, dimaksudkan agar anak dengan bereksperimen akan memperoleh pengalaman kerja langsung, baik dari alat maupun reaksi yang terjadi dalam percobaan itu, (3) Usaha eksperimen untuk memahami suatu konsep, agar anak lebih mudah untuk menerima konsep. Dengan pengalaman langsung maka pengetahuan yang diperoleh anak akan melekat lebih lama, (4) Eksperimen sebagi model, dimaksudkan agar guru melaksanakan suatu usaha untuk mempermudah proses pembelajarannya dengan melakukan pendekatanpendekatan yang memungkinkan anak lebih memahami konsep yang diajarkan. (5) Sebagai usaha pengulangan, melalui eksperimen guru mengulangi teoritis yang telah disampaikan, dan konsep yang telah diajarkan akan lebih kongkrit jika melalui pelaksanaan eksperimen. Upaya tersebut memungkinkan anak untuk meningkatkan keterampilan proses sains meliputi, mengamati, mengklarifikasi dan menyimpulkan. Hal ini jika dibandingkan dengan penelitian terdahulu memiliki perbedaan yaitu dalam setiap materi yang digunakan. Apabila dilihat dari hasil penelitian ini, ternyata pembelajaran sains berbasis eksperimen ini selain mengajak anak untuk belajar berdasarkan pengalaman tetapi lebih jauhnya dalam mengembangkan keterampilan proses sains meliputi, mengamati, mengklarifikasi dan menyimpulkan dan dapat memberikan pengaruh yang signifikan untuk menemukan masalah dan memecahkan suatu masalah. Sehubung dengan itu, keterampilan dan proses dalam sains memiliki hubungan bagi semua orang yang berkepentingan dengan pendidikan atau dunia sains wellington (dalam, white, 1991, hlm.5) wellington (dalam, white, 1991, hlm.5).

\section{SIMPULAN}

Berdasarkan hasil penelitian dan pengujian hipotesis tentang pengaruh pembelajaran sains berbasis eksperimen terhadap keterampilan proses sains pada anak usia dini, maka dapat disimpulkan bahwa:

1. Keterampilan proses sains anak sesudah menggunakan pembelajaran sains berbasis eksperimen pada anak kelompok Taman kanak-kanak Lab UPI Bandung pada anak kelompok kontrol 9 orang berada pada kategori C (Cukup) menggunakan pembelajaran sains konvensional dan anak kelompok eksperimen menggunakan pembelajaran berbasis sains berbasis eksperimen pada umumnya 9 orang berada pada kategori yang B (Baik). Keterampilan proses sains anak sebelum menggunakan pembelajaran sains berbasis eksperimen pada anak kelompok B TK Lab UPI Bandung pada anak kelompok kontrol menggunakan pembelajaran sains demonstrasi dan anak kelompok eksperimen menggunakan pembelajaran berbasis sains berbasis eksperimen pada umumnya berada pada kategori K (Kurang), Artinya berdasarkan variabelnya keterampilan proses sains pada seluruh anak kelompok kontrol 9 orang dengan kategori $\mathrm{K}$ (Kurang) dan kelompok eksperimen 8 orang dengan kategori $\mathrm{K}$ (Kurang ), 1 orang dengan kategori C (cukup) keterampilan proses sains dalam proses berkembang.

2. Keterampilan proses sains anak sesudah menggunakan pembelajaran sains berbasis eksperimen pada anak kelompok TK Lab UPI Bandung pada anak kelompok kontrol 9 orang 
berada pada kategori C (Cukup) menggunakan pembelajaran sains demonstrasi dan anak kelompok eksperimen menggunakan pembelajaran berbasis sains berbasis eksperimen pada umumnya 9 orang berada pada kategori yang B (Baik).

Terdapat pengaruh yang signifikan dari penerapan pembelajaran sains berbasis eksperimen terhadap keterampilan proses sains pada anak kelompok B TK Lab UPI Bandung pada kelompok kontrol menggunakan pembelajaran sains demonstrasi dan kelompok eksperimen menggunakan pembelajaran sains berbasis eksperimen. Hasil perhitungan uji independent sample $\mathrm{T}$ test menunjukkan adanya pengaruh pembelajaran sains berbasis eksperimen terhadap keterampilan proses sains pada anak usia dini. Artinya, keterampilan proses sains pada anak dapat dipengaruhi oleh pembelajaran sains berbasis eksperimen.

\section{DAFTAR RUJUKAN}

Undang-Undang Republik Indonesia Nomor 20 Tahun 2003 tentang Sistem. Pendidikan Nasional.

Djamarah, S. B. \& Zain, A. (2010). Strategi Belajar Mengajar. Jakarta: Rineka Cipta.

NAP. (1996). National Science Education Standards. United States Of America. Educational Research And Review Vol. 5 (10), Pp. 584-592, October 2010. Available Online At
Http://Www.Academicjournals.Org/Er r2. (12 September 2018)

Poedjiadi, A. (2010). Sains Teknologi Masyarakat. Bandung: PT Remaja Rosdakarya.

Poincare, Richard A. Duschl, Heidi A. Schweingruber, And Andrew W. Shouse. (2007). Taking Science To School: Learning And Teaching Science In Grades K-8 Doi 10.17226/11625.

Http://Nap.Edu/11625 (diakses: 7 Oktober 2018).

Bilim, E. (2013). Science Learning Experiences In Kindergarten And Children's Growth In Science Performance In Elementary Grades. Education And Science. 2013, Vol. 38, No 167.

Duru, A. (2010). The Experimental Teaching In Some Of Topics Geometry . Vol. 5 (10), Pp. 584-592, October 2010 Available Online At Http://Www.Academicjournals.Org/Er r2 Issn 1990-3839 @2010 Academic Journals Full (5 november 2018)

Sugiyono. (2016). Metode Penelitian Pendidikan Pendekatan Kuantitatif, Kualitatif, Dan R\&D. Bandung: Alfabeta.

Suryabrata,S. (2014). Metodologi Penelitian. Jakarta: PT Rajagrafindo Persada.

UNESCO. (1999). Current Challenges In Basic Science Education. Unescco: Paris.

Anderson, M.H. (2007). Perspectives For Pharmacy Educators Successful Teaching Excellence Dale's Cone Of Experience. University Of Kentucky. 